\title{
Chemical composition, Functional properties and performance of soybean and wheat flour blends in instant fried noodles
}

\author{
Peter Isah Akubor*1 and Taibat Oluwaseun Fayashe ${ }^{2}$ \\ ${ }^{1}$ Department of Food Science and Technology, Federal Univ., Wukari, Taraba State, Nigeria \\ ${ }^{2}$ Department of Food Science and Technology, Kogi State Univ., Anyigba, Kogi State, Nigeria \\ *Email: akuborpeter@gmail.com
}

\begin{abstract}
The study evaluated the quality of fried instant noodles supplemented with soybean flour. Flour was prepared from soybean seeds. The chemical composition and functional properties of wheat flour and soybean flour were determined. The soybean flour was used to substitute 10,20,30,40 and 50\% of wheat flour in fried noodles which were assessed for the chemical composition, sensory and cooking characteristics. The soybean flour contained higher amounts of protein $(36.16 \%)$, ash $(1.56 \%)$, crude fiber $(2.65 \%)$ but less carbohydrate $(33.51 \%)$, fat $(1.90 \%)$ and moisture $(7.14 \%)$ contents than wheat flour. The wheat flour contained $6.76 \%$ protein, $0.57 \%$ ash, $0.63 \%$ crude fiber, $2.38 \%$ fat and $10.86 \%$ moisture. The soybean flour had higher water absorption capacity, bulk density, foaming capacity, foam stability and emulsion stability than wheat flour. The water absorption capacity increased while the oil absorption capacity, foaming and emulsifying properties decreased with increase in the level of soybean flour in the blends. The fried instant noodles containing $40 \%$ soybean flour was not significantly different $(\mathrm{p}>0.05)$ from the $100 \%$ wheat flour noodles in the sensory attributes evaluated. The fried noodles containing $40 \%$ soybean flour was significantly higher $(\mathrm{p}<0.05)$ in the protein, ash, crude fiber and fat contents than the $100 \%$ wheat flour noodles. The cooking time (9.20min), cooking loss $(10.10 \%)$ and weight increase $(120 \%)$ of the instant fried noodles containing $40 \%$ soybean flour were higher than those of the $100 \%$ wheat flour noodles. The cooking time, cooking loss and weight increase of the $100 \%$ wheat flour noodles were $7.19 \mathrm{~min}, 8.62 \%$ and $113.20 \%$, respectively. The cooking time, cooking loss and percent weight increase increased while the volume increase decreased as the level of soybean flour increased in the noodles.
\end{abstract}

Keywords: Functional properties, instant fried noodles, wheat flour blends, soybean.

Paper cited: Akubor, P.I. and Fayashe, T.O. (2018). Chemical composition, Functional properties and performance of soybean and wheat flour blends in instant fried noodles. South Asian Journal of Food Technology and Environment, 4(2): 690-699.

\section{Introduction}

Noodles are very popular wheat food products that are consumed by all age groups due to their simple preparation requirement, desirable sensory attributes, long shelf life, versatility and nutritive value (Compreeda et al., 1987). The consumption of wheat noodles is globally second to bread (Omeire et al., 2014). However, the nutrient composition of noodles varies widely depending on the type, quality and quantity of the constituent materials as well as the processing methods (Sanni et al., 2007). Thus noodles which are usually prepared from soft wheat are rich in carbohydrate but low in protein content and deficient in essential amino acids, dietary fiber, vitamins, minerals and phytochemicals (Nago, 1996). Thus, noodle products which represent a major end use of wheat flour are suitable for enhancing health after incorporating sources of essential nutrients and phytochemicals. In this regard, the development of fortified noodles is the latest trend in noodle production. Noodles have been fortified with peanuts, soybean, sweet potato, banana flour, apricot kernel, millet, sorghum, cocoyam, breadfruit, unripe banana flour etc. (Ubbor and Nwaogu, 2010; Ritthnuangde et al., 2011; Adenuga et al., 2012). 
Soybean (Glycine max) is grown in the tropical, subtropical and temperate countries of the world. Soybean contains $36 \%$ protein, $20 \%$ fat, $30 \%$ carbohydrate, excellent amounts of dietary fiber, vitamins and minerals (Liu, 2000). Soybean is rich in unsaturated fatty acids, low in saturated fatty acids and a good source of omega-3 fatty acids (Iwe, 2003). Omega-3 fatty acids in soybeans may reduce the risk of heart disease, control blood sugar (Iwe, 2003). Soybean is a cheap source of protein that is superior to all other plant foods because of its balance of essential amino acids. Thus, soybean is used to fortify foods such as noodles, pastas, bread, crackers, muffins, doughnut, cakes, rolls, cookies among others (Adenuga et al., 2012; Omeire et al., 2014). The use of soybean in this way helps to reduce the risk of malnutrition particularly protein deficiency which is prevalent in many parts of African where animal protein is too expensive for most of the populations (Liu, 2000). Soybean also contains phytochemicals such as isoflavones (genistein and diadzein) and glycitein (Liu, 2000). Thus, soybeans promote desirable health benefits as soy flavones provide beneficial effect against most of the common disorders affecting human including cancer (Jiang et al., 2000). The physiological effects of soy flavones have been reported to include lowering risk of cardiovascular, inhibition of bone resorption, growth inhibition of human breast and prostate cancer, antioxidant properties and ability to lower cholesterol level (Jiang et al., 2000). These properties have increased the use of soybean in food formulations. In this regard, noodles from wheat flour and soybean flour blends would improve the protein quality and provide other essential nutrients and phytochemicals. However, many studies have reported that substitution of wheat flour with legume protein such as soybean could adversely affect the overall quality of noodles.

Many convenience foods such as noodles are prepared by frying as it alters eating quality and imparts characteristic color and flavor. Drying by frying is a very fast process. Water vaporizes quickly from the surface of the noodles upon dipping into the hot oil. Dehydration of the exterior surface causes water to migrate from the interior to the exterior of the noodle strands. Eventually, some of the water in the noodles is replaced by oil. Many tiny holes are created during the frying process due to the mass transfer and they serve as channel for the water upon rehydration in hot water. It usually takes 3-4 minutes to cook or soak instant fried in hot water before consumption. However, instant fried noodle supplemented with soybean flour is yet to appear in the market. Such noodle would be adequate in protein, fiber and essential phytochemicals which would impact positively on the health of the consumers. Thus, the objective of the study was to determine the chemical composition, functional properties and performance of soybean and wheat flour blends in instant fried noodles

\section{Materials and Methods}

Source of raw materials; The wheat flour and soybeans were purchased from Anyigba Main Market, Kogi State, Nigeria. The wheat flour was sieved through a 500um sieve and then packaged in high density polyethylene bags (HDPE) prior to use.

Preparation of soybean flour: The soybean seeds were sorted, winnowed and then washed in distilled water contained in a basin. The seeds were soaked in distilled water for 10 hours (1:10, seed: water). The hydrated seeds were dehulled manually, washed and sun dried $\left(32^{\circ} \mathrm{C}\right)$ to constant weight. The dried kernels were milled in attrition mill, sieved through 500um sieve and then packed in HDPE bags prior to use.

Flour blending: The soybean flour was used to substitute 10,20,30, 40 and $50 \%$ of wheat flour in a Kenwood food blender that was operated at full speed (1200rpm) for $10 \mathrm{~min}$. The flour blends were packaged in HDPE bags prior to use.

Preparation of noodles: The noodles were prepared as described by Ubbor and Nwaogu (2010). The recipe used for the preparation of the noodles is given in Table 1. Four hundred gram of wheat was weighed and $2 \mathrm{~g}$ salt was sprinkled on the flour and then mixed thoroughly. One whole egg and two eggs yolk were slightly beaten and poured on the flour and thereafter, mixed thoroughly. The water was added to the mixture and formed into dough. The dough was wrapped in a polyethylene bag, rested for 30 minutes and then kneaded. The dough was put into a pasta making and cut into strands. The cut out dough strands were steamed for 5 minutes, fried in soybean oil at $120^{\circ} \mathrm{C}$ for 2 minutes, cooled and then packaged in high density polyethylene bags prior to use. 
Evaluation of functional properties: The bulk density, water and oil absorption capacities were determined as described by Onimawo and Akubor (2012). The foaming capacity and foam stability were determined following the method outlined by Kinsella (1987). The emulsion activity and emulsion stability were determined as described by Sathe et al., (1982).

Determination of proximate composition: The crude protein (Kjeldahl method, $\mathrm{N} \times 6.25$ ), fat (solvent extraction), ash, crude fiber and moisture contents were determined as described by the AOAC (2010) methods. The carbohydrate content was calculated by difference as: $\{100$ - (\% Protein $+\%$ Fat $+\%$ Ash $+\%$ Crude fiber $+\%$ Moisture $)\}$. The calorie content was calculated using at water factor $(4 \times \%$ protein $+4 \times \%$ carbohydrate $+9 \times \%$ Fat).

Determination of mineral composition: The sodium and potassium contents were determined by flame photometry (AOAC, 2010). The calcium, iron, phosphorus and magnesium contents were determined by atomic absorption spectrophotometry as described by the AOAC (2010) methods.

Sensory evaluation: Twenty trained panelists were randomly selected from staff and students of the Department of Food, Nutrition and Home sciences, Kogi State University, Anyigba. The samples were evaluated for color, taste, texture, flavor and overall acceptability on a 9-point Hedonic scale where $1=$ dislike extremely and $9=$ like extremely as described by Ihekoronye and Ngoddy (1985). The samples were presented to the panelists in 3 digit coded white plastic plates. The order of presentation of the samples to the panelists was randomized. The panelists were presented with clean tap water to rinse mouths in between the evaluations. The sensory evaluation was carried out in a sensory evaluation laboratory under adequate lighting and ventilation.

Determination of cooking time: The optimum cooking time was the time required for the opaque central core of the noodles to disappear when squeezed gently between two glass plates after cooking. Optimum cooking time of the noodles was determined according to the method of Sui et al., (2006).The noodle sample (5g) was inserted into a beaker containing $75 \mathrm{~mL}$ distilled water and one strip was crushed between two glasses every 30 seconds. The cooking was continued until the white fraction of the central core of the crushed noodles disappeared and the time that passed was recorded as the optimum cooking time.

Determination of cooking loss: The cooking loss was determined according to the method described by Lii and Chang (1981). The noodle samples (25g) of $5 \mathrm{~cm}$ length were put into a beaker containing $250 \mathrm{ml}$ boiling water on a hot plate. The noodles were stirred gently with a glass rod. After cooking for 10 minutes, the noodles were filtered through a nylon screen. The beaker, noodles and screen were washed with distilled water. The combined filtrate was placed in a dried tarred beaker $\left(\mathrm{W}_{1}\right)$ and dried at $80^{\circ} \mathrm{C}$ and then at $100^{\circ} \mathrm{C}$ to constant weight $\left(\mathrm{W}_{2}\right)$. The moisture content of the pre cooked noodles was recorded as $\mathrm{W}_{3}$. The solids loss during cooking was calculated as $\left\{\left(\mathrm{W}_{2}-\mathrm{W}_{1}\right) /(25-\right.$ $\left.\left.\mathrm{W}_{3}\right)\right\} \times 100$, where $25 \mathrm{~g}=$ weight of the noodles.

Determination of volume increase: The volume increase was evaluated according to the method described by Fasasi and Karim (2011). The noodle $(20 \mathrm{~g})$ was cooked in boiling water $(200 \mathrm{ml})$ on the basis of their optimum cooking time, rested for 5 minutes and transferred to a beaker filled with 200 $\mathrm{ml}$ distilled water. The volume of water over flown from the beaker was recorded. The same procedure was repeated for the uncooked noodles. The percentage volume between the volume of overflowed water for cooked and uncooked noodles was determined.

Determination of weight increase: The weight increase was evaluated according to the method described by Sui et al., (2006). The cooked and drained noodles were rested for 5 minutes. The weight was recorded and the weight increase was calculated on the basis of difference between the weight of the cooked and uncooked noodles.

Statistical analysis: All the experiments were conducted in triplicates in completely randomized design. The data were analyzed by analysis of variance using Statistical Package for Social Sciences (SPSS) software, version 17.0, 2007. Means where significantly different were separated by the least significant difference (LSD) test. Significance was accepted at $\mathrm{p}<0.05$. 


\section{Results and Discussion}

Functional properties: Table 1 shows the functional properties of wheat flour, soybean flour and the flour blends. Functional properties are characteristics of flour that affect its behavior and that of the products to which it is added during food processing. The wheat flour had $0.70 \mathrm{~g} / \mathrm{cm}^{3}$ bulk density while the bulk density of soybean flour was $0.61 \mathrm{~g} / \mathrm{cm}$. The bulk densities of the blends were not significantly $(p<0.05)$ affected by the addition of soybean flour where values slightly varied from 0.65 to $0.67 \mathrm{~g} / \mathrm{cm}^{3}$. Bulk density is a measure of the heaviness of flour. It also measures the porosity of a material and affects the design of a package. In this regard, bulk density would be useful for determining the packaging requirement of flour as well as in material handling and application in wet processing of food. Thus, the low bulk densities of the flours evaluated in this study makes their packaging economical. The complementary foods that would be prepared from the flour blends will have low dietary bulk. This is important for such foods because high bulk limits calorie and nutrients intake from food and infants will not be able consume enough of high dietary bulk foods to meet their energy and nutrients requirements. A diet with low dietary bulk would not form thick gel with high viscosity, plasticity and elasticity (Onimawo and Akubor, 2012).

The wheat flour absorbs more oil (120\%) than soybean flour $(119 \%)$, suggesting higher amount of a polar amino acids in wheat flour. Onimawo and Akubor (2012) ascribed oil absorption capacity to mainly physical entrapment of oil which indicates the rate at which proteins bind to fat in food formulations. High oil absorption capacity has been suggested to be useful in food formulations because fats improve flavor and mouth feel of foods (Akubor, 2017). The water absorption capacity of soybean flour $(216 \%)$ was higher than that of wheat flour $(98 \%)$. The soybean flour contained higher amounts of hydrophilic constituents such as protein and crude fiber than wheat flour (Table 2). Akpata and Akubor (1999) showed that water absorption capacity is influenced mainly by the nature of the hydrophilic constituents and to some extent the $\mathrm{pH}$ and nature of the protein. The low oil absorption capacity of soybean flour may have enhanced its water absorption capacity. The water absorption capacity $(\mathrm{g} / \mathrm{ml})$ of the flour blends increased gradually from $110-148 \%$ with the level of soybean flour due addition effect. High water absorption capacity is desirable as it increases the yield of products but not for pasta where it makes pasta soft and less firm (1996). In starchy foods, high water absorption stabilizes starches against syneresis during retorting and freezing (Onimawo and Akubor, 2012). High water absorption capacity is also useful in the development of ready-to eat foods where it promotes product cohesiveness (Onimawo and Akubor, 2012). The soybean flour had higher capacity to form and stabilize foam probably due to its higher protein content over that of wheat flour (Table 2). Akubor and Eze (2016) noted the dependent of foaming capacity and foam stability on protein concentration, protein solubility among other factors. Foaming capacity and foam stability of the flour blends decreased with increase in the mount soybean flour. This is in agreement with the report by Akubor (2017) that foaming properties are not additives. The ability of food to form good foam is associated with flexible protein molecules which reduces surface tension (Kinsella, 1987). On the other hand, the inability of food to produce food is linked to highly ordered globular proteins which resist surface denaturation (Kinsella, 1987). Foamability is related to the ability of proteins to adsorb rapidly at the air- water interface during bubbling and also on the ability of proteins to undergo rapid conformational change and arrangement at the interface (Igbokwe et al., 2016). For food to form stable foam, the proteins must have the capacity to form cohesive viscoelastic film through intermolecular interactions during processing (Eguono and Akubor, 2016). Foam formation and foam stability are influenced by the type of protein, $\mathrm{pH}$, processing methods, viscosity and surface tension (Eguono and Akubor, 2016). Akubor and Chukwu (1999) reported that foams improve the texture and appearance of processed foods. Good foaming capacity and foam stability are useful qualities for flours intended for deep fat fried products such as fried noodles. The wheat flour had higher emulsion capacity $(71 \%)$ and emulsion stability $(50 \%)$ than those of the soybean flour. The emulsion capacity and emulsion stability of soybean flour were 37 and $40 \%$, respectively. The high fiber and carbohydrate contents of soybean flour (Table 2) may have discouraged the formation and stabilization of emulsion (Igbokwe et al., 2016). Carbohydrates have high molecular weight and low hydrophobicity (Kinsella, 1987). These properties do not favor the formation and 
stabilization of emulsion (Akubor, 2016). The emulsion capacity and emulsion stability of the blends decreased with the level of soybean flour in the blends. The emulsifying properties of foods are attributed to molecular weight, conformation, polarity and flexibility of the proteins and exposure of the hydrophobic domains (Sathe et al., 1982). These properties facilitate the unfolding (denaturation) and adsorption of proteins at the water-oil interface (Sathe et al., 1982). Consequently, protein stabilized emulsions exhibit negligible changes in droplet size distribution over time (Kinsellal,1987). The capacity of proteins to enhance the formation and stabilization of emulsion is important in many applications such as in cakes, bread etc. The low emulsion properties of the flours may affect their use for stabilizing colloidal food systems. The least gelation concentrations of the flours were low where values ranged between 6 and $8 \%(\mathrm{w} / \mathrm{v})$. The wheat flour $(6 \%)$ had lower least gelation concentration than soybean flour (8\%). Sathe et al., (1982) associated the gelling properties of flours to the different proportions of carbohydrate, protein and fat in the flour. However, Onimawo and Akubor (2012) suggested that the interaction between these constituents affect functional properties of foods.

Chemical composition: The chemical composition of the flour blends and the noodles is shown in Table 2. The moisture content the soybean four $(7.14 \%)$ was lower that of wheat flour $(10.86 \%)$. The moisture contents of the flour blends ranged between 6.32 and $7.54 \%$. The moisture content decreased with the level of soybean flour in the blends due to the lower moisture content of the soybean flour.

Table 1: Functional properties of wheat flour, soybean flour and the blends

\begin{tabular}{|c|c|c|c|c|c|c|c|c|}
\hline WF:SBF & $\begin{array}{c}\text { WAC, } \\
(\mathbf{\%})\end{array}$ & $\begin{array}{c}\text { OAC } \\
(\%)\end{array}$ & $\begin{array}{c}\text { BD } \\
(\mathbf{g} / \mathbf{m l})\end{array}$ & FC (\%) & FS ( \%) & EC (\%) & ES (\%) & $\begin{array}{c}\text { LGC } \\
(\%)\end{array}$ \\
\hline $100: 0$ & $98^{\mathrm{g}}$ & $120^{\mathrm{a}}$ & $0.70^{\mathrm{a}}$ & $60^{\mathrm{a}}$ & $65^{\mathrm{a}}$ & $71^{\mathrm{a}}$ & $50 \mathrm{a}$ & $6^{\mathrm{b}}$ \\
\hline $0: 100$ & $216^{\mathrm{a}}$ & $119^{\mathrm{b}}$ & $0.61^{\mathrm{a}}$ & $50^{\mathrm{e}}$ & $20^{\mathrm{g}}$ & $37^{\mathrm{g}}$ & $40^{\mathrm{f}}$ & $8^{\mathrm{a}}$ \\
\hline $90: 10$ & $110^{\mathrm{f}}$ & $119_{\mathrm{b}}$ & $0.65^{\mathrm{a}}$ & $58^{\mathrm{b}}$ & $60^{\mathrm{b}}$ & $66^{\mathrm{b}}$ & $46^{\mathrm{b}}$ & $6^{\mathrm{b}}$ \\
\hline $80: 20$ & $120^{\mathrm{e}}$ & $114^{\mathrm{c}}$ & $0.66^{\mathrm{a}}$ & $55^{\mathrm{c}}$ & $58^{\mathrm{c}}$ & $63^{\mathrm{c}}$ & $45^{\mathrm{c}}$ & $6^{\mathrm{b}}$ \\
\hline $70: 30$ & $129^{\mathrm{d}}$ & $112^{\mathrm{d}}$ & $0.65^{\mathrm{a}}$ & $54^{\mathrm{d}}$ & $50^{\mathrm{d}}$ & $60^{\mathrm{d}}$ & $43^{\mathrm{d}}$ & $8^{\mathrm{a}}$ \\
\hline $60: 40$ & $140^{\mathrm{c}}$ & $111^{\mathrm{e}}$ & $0.67^{\mathrm{a}}$ & $50^{\mathrm{e}}$ & $47^{\mathrm{e}}$ & $56^{\mathrm{e}}$ & $41^{\mathrm{e}}$ & $8^{\mathrm{a}}$ \\
\hline $50: 50$ & $148^{\mathrm{b}}$ & $109^{\mathrm{f}}$ & $0.65^{\mathrm{a}}$ & $50^{\mathrm{e}}$ & $42^{\mathrm{f}}$ & $51^{\mathrm{f}}$ & $40^{\mathrm{f}}$ & $8^{\mathrm{a}}$ \\
\hline
\end{tabular}

Values are means of 3 replicates. Means within a column with the same superscript were not significantly different (p $>0.05)$.WF, wheat flour; SBF, soybean flour; WAC, water absorption capacity; OAC, oil absorption capacity; BD, bulk density; FC, foaming capacity; FS, foam stability; EC, emulsion capacity; ES, emulsion stability

Table 2: Proximate composition (\%) of wheat flour, soybean flour, flour blends and noodle

\begin{tabular}{|c|c|c|c|c|c|c|}
\hline $\begin{array}{c}\text { Noodle } \\
\text { WF:SBF }\end{array}$ & Moisture & Fat & Protein & Ash & Crude fiber & Carbohydrate \\
\hline $0: 100$ & $7.14^{\mathrm{b}}$ & $1.90^{\mathrm{h}}$ & $36.16^{\mathrm{a}}$ & $1.56^{\mathrm{c}}$ & $2.65^{\mathrm{a}}$ & $33.51^{\mathrm{e}}$ \\
\hline $100: 0$ & $10.86^{\mathrm{a}}$ & $2.38^{\mathrm{g}}$ & $6.70^{\mathrm{g}}$ & $0.57^{\mathrm{c}}$ & $0.63^{\mathrm{c}}$ & $78.82^{\mathrm{a}}$ \\
\hline $90: 10$ & $7.35^{\mathrm{b}}$ & $6.69^{\mathrm{f}}$ & $12.25^{\mathrm{f}}$ & $1.59^{\mathrm{c}}$ & $1.05^{\mathrm{b}}$ & $71.08^{\mathrm{b}}$ \\
\hline $80: 20$ & $6.87^{\mathrm{b}}$ & $8.83^{\mathrm{e}}$ & $14.79^{\mathrm{e}}$ & $1.89^{\mathrm{c}}$ & $1.23^{\mathrm{b}}$ & $66.40^{\mathrm{c}}$ \\
\hline $70: 30$ & $6.58^{\mathrm{b}}$ & $10.1^{\mathrm{d}}$ & $16.50^{\mathrm{d}}$ & $2.12^{\mathrm{b}}$ & $1.23^{\mathrm{b}}$ & $63.40^{\mathrm{c}}$ \\
\hline $60: 40$ & $6.34^{\mathrm{b}}$ & $12.27^{\mathrm{c}}$ & $18.32^{\mathrm{c}}$ & $2.37^{\mathrm{b}}$ & $1.48^{\mathrm{b}}$ & $59.2^{\mathrm{d}}$ \\
\hline $50: 50$ & $6.52^{\mathrm{b}}$ & $14.44^{\mathrm{b}}$ & $18.9^{\mathrm{c}}$ & $2.43^{\mathrm{b}}$ & $1.76^{\mathrm{b}}$ & $56.13^{\mathrm{d}}$ \\
\hline Noodle & $7.54^{\mathrm{b}}$ & $16.54^{\mathrm{a}}$ & $19.13^{\mathrm{b}}$ & $4.52^{\mathrm{a}}$ & $1.55^{\mathrm{b}}$ & $56.71^{\mathrm{d}}$ \\
\hline WF noodle & $11.0^{\mathrm{a}}$ & $10.0^{\mathrm{d}}$ & $12.0^{\mathrm{f}}$ & $1.50^{\mathrm{c}}$ & $1.80 \mathrm{~b}$ & $63.70^{\mathrm{c}}$ \\
\hline
\end{tabular}

Values are means of 3 replicates. Means within a column with the same superscript were not significantly different $(\mathrm{p}>0.05)$.Abbreviations as defined in Table 1 
Table 3: Mineral composition (mg/100g) of wheat-soybean flour blends and noodle

\begin{tabular}{|c|c|c|c|c|c|c|}
\hline $\begin{array}{c}\text { Noodles } \\
\text { WF:SBF }\end{array}$ & Calcium & Magnesium & Sodium & Potassium & Phosphorus & Iron \\
\hline $0: 100$ & $50.8^{\mathrm{g}}$ & $48.3^{\mathrm{h}}$ & $18.3 \mathrm{a}$ & $110.3^{\mathrm{d}}$ & $140.3^{\mathrm{g}}$ & $1.2^{\mathrm{c}}$ \\
\hline $100: 0$ & $42.9^{\mathrm{h}}$ & $84.2^{\mathrm{g}}$ & $18.1^{\mathrm{a}}$ & $73.50^{\mathrm{e}}$ & $42.7^{\mathrm{h}}$ & $1.9^{\mathrm{b}}$ \\
\hline $90: 10$ & $120.4^{\mathrm{f}}$ & $101.5^{\mathrm{f}}$ & $18.2^{\mathrm{a}}$ & $120.2^{\mathrm{c}}$ & $257.9^{\mathrm{f}}$ & $1.2^{\mathrm{c}}$ \\
\hline $80: 20$ & $150.6^{\mathrm{e}}$ & $108.4^{\mathrm{e}}$ & $18.2^{\mathrm{a}}$ & $137.1^{\mathrm{b}}$ & $259.2^{\mathrm{e}}$ & $1.2^{\mathrm{c}}$ \\
\hline $70: 30$ & $190.5^{\mathrm{c}}$ & $123.1^{\mathrm{d}}$ & $18.2^{\mathrm{a}}$ & $141.3^{\mathrm{a}}$ & $289.6^{\mathrm{d}}$ & $1.9^{\mathrm{b}}$ \\
\hline $60: 40$ & $197.2^{\mathrm{b}}$ & $132.5 \mathrm{~b}$ & $18.2^{\mathrm{a}}$ & $141.3^{\mathrm{a}}$ & $344.3^{\mathrm{c}}$ & $2.2^{\mathrm{b}}$ \\
\hline $50: 50$ & $200.9^{\mathrm{a}}$ & $198.4^{\mathrm{a}}$ & $18.3^{\mathrm{a}}$ & $143.6^{\mathrm{a}}$ & $463.4^{\mathrm{b}}$ & $2.4^{\mathrm{b}}$ \\
\hline Noodle & $170.7^{\mathrm{d}}$ & $120.5^{\mathrm{c}}$ & $90.2^{\mathrm{a}}$ & $110.3^{\mathrm{d}}$ & $484.8^{\mathrm{a}}$ & $3.1 \mathrm{a}$ \\
\hline
\end{tabular}

Values are means of 3 replicates. Means within a column with the same superscript were not significantly different ( $p>0.05)$. Abbreviations as defined in Table 1.

Table 4: Sensory properties of instant fried noodles prepared from wheat and soybean flour blends

\begin{tabular}{|c|c|c|c|c|c|}
\hline $\begin{array}{c}\text { Noodles } \\
\text { WF.SBF }\end{array}$ & Colour & Flavour & Texture & Taste & $\begin{array}{c}\text { Overall } \\
\text { acceptability }\end{array}$ \\
\hline $100: 0$ & $8.68^{\mathrm{a}}$ & $7.60^{\mathrm{a}}$ & $8.32^{\mathrm{a}}$ & $7.60^{\mathrm{a}}$ & $8.10^{\mathrm{a}}$ \\
\hline $90: 10$ & $7.45^{\mathrm{b}}$ & $6.81^{\mathrm{b}}$ & $7.20^{\mathrm{b}}$ & $7.40^{\mathrm{a}}$ & $7.75^{\mathrm{b}}$ \\
\hline $80: 20$ & $6.50^{\mathrm{c}}$ & $6.90^{\mathrm{b}}$ & $7.00^{\mathrm{b}}$ & $7.30^{\mathrm{a}}$ & $7.50^{\mathrm{b}}$ \\
\hline $70: 30$ & $7.60^{\mathrm{b}}$ & $7.00^{\mathrm{a}}$ & $6.83^{\mathrm{c}}$ & $7.10^{\mathrm{a}}$ & $6.92^{\mathrm{c}}$ \\
\hline $60: 40$ & $8.20^{\mathrm{a}}$ & $7.92^{\mathrm{a}}$ & $7.90^{\mathrm{b}}$ & $7.70^{\mathrm{a}}$ & $7.99^{\mathrm{b}}$ \\
\hline $50: 50$ & $6.32^{\mathrm{c}}$ & $6.20^{\mathrm{b}}$ & $6.93^{\mathrm{c}}$ & $6.93^{\mathrm{b}}$ & $6.50^{\mathrm{c}}$ \\
\hline
\end{tabular}

Values are means of 20 replicates. Means within a column with the same superscript were not significantly different $(\mathrm{p}>0.05)$.Abbreviations as defined in Table 1 .

Table 5: Cooking properties of instant fried noodles prepared from wheat and soybean flour blends

\begin{tabular}{|c|c|c|c|c|}
\hline $\begin{array}{c}\text { Noodles } \\
\text { WF:SBF }\end{array}$ & $\begin{array}{c}\text { Cooking time } \\
\text { (min) }\end{array}$ & $\begin{array}{c}\text { Cooking loss } \\
\mathbf{( \% )}\end{array}$ & $\begin{array}{c}\text { Volume increase } \\
\mathbf{( \% )}\end{array}$ & $\begin{array}{c}\text { Weight increase } \\
(\mathbf{\%})\end{array}$ \\
\hline $90: 10$ & $8.21^{\mathrm{b}} \pm 0.01$ & $8.81^{\mathrm{d}} \pm 0.01$ & $240^{\mathrm{a}} \pm 0.01$ & $112.58^{\mathrm{f}} \pm 0.01$ \\
\hline $80: 20$ & $8.29^{\mathrm{b}} \pm 0.02$ & $9.2^{\mathrm{c}} \pm 0.02$ & $200^{\mathrm{d}} \pm 0.01$ & $117.0^{\mathrm{c}} \pm 0.01$ \\
\hline $70: 30$ & $8.32^{\mathrm{b}} \pm 0.01$ & $9.70^{\mathrm{c}} \pm 0.01$ & $210 \mathrm{c} \pm 0.01$ & $119.0^{\mathrm{d}} \pm 0.01$ \\
\hline $60: 40$ & $9.20^{\mathrm{a}} \pm 0.01$ & $10.10^{\mathrm{b}} \pm 0.02$ & $170^{\mathrm{d}} \pm 0.01$ & $120.0^{\mathrm{b}} \pm 0.01$ \\
\hline $50: 50$ & $9.45^{\mathrm{a}} \pm 0.01$ & $11.25^{\mathrm{a}} \pm 0.02$ & $150^{\mathrm{e}} \pm 0.01$ & $124.0^{\mathrm{a}} \pm 0.01$ \\
\hline $100: 0$ & $7.19^{\mathrm{c}} \pm 0.01$ & $8.62^{\mathrm{d}} \pm 0.01$ & $220^{\mathrm{b}} \pm 0.01$ & $113.30^{\mathrm{e}} \pm 0.06$ \\
\hline
\end{tabular}

Values are means of 3 replicates. Means within a column with the same superscript were not significantly different $(\mathrm{p}>0.05)$.Abbreviations as defined in Table in Table 1.

The low moisture contents $(6.32-10.86 \%)$ would enhance the stability of the flours. Moisture influences microbial activities and chemical reactions in foods on storage (Puwani et al., 2006). Akubor (2017) established that low moisture content is important for the shelf life stability of food products. The fat contents of the blends increased as the level of soybean flour increased in the blend due to additive effect for soybean flour contained higher amount of fat than wheat flour. The decrease in carbohydrate content was influenced by the high protein content of the soybean flour. Carbohydrate provides economic and quick source of energy. Carbohydrates spare proteins so that proteins can be used for their more important function and adequate supply of carbohydrate determines when protein would be metabolized for energy. Ash content is an indication of the minerals in foods which is of good amount in soybean flour $(1.56 \%)$. Soybean flour provides high quality source of protein compared to other leguminous crops (Iwe, 2003) which is the reason why the protein content of the blends increased with the level of soybean flour. The fiber contents of the flour blends (1.05-1.70) were high when compared to that of wheat flour $(0.63 \%)$. Fiber is known to prevent a number of non infectious diseases (Anderson et al., 1994). The high protein content of SBF makes it a useful supplement in noodles. The protein content of the noodle supplemented with soybean flour contained higher 
amount of protein than that of the $100 \%$ noodle because of the contribution from soybean flour. The protein content of the noodle supplemented with soybean flour $(19.13 \%)$ was well above the $15 \%$ recommended as the minimum level for complementary foods (WHO, 2003). Similarly, the high fat of the SBF upgraded the fat content of the noodle supplemented with soybean flour. The fat content of the noodles were contributed by the fat used in frying process employed in the preparation of the noodles. The fat content in the range of 13.37$21-50 \%$ was reported for wet noodle (Reungmaneepaitoon, 2009 ).The high fat content of the noodle supplemented with SBF contribute to the texture and flavor of the noodles which would prolong satiety and facilitate the absorption of fat soluble vitamins( Akubor, 2016). The complementary effect of blending two flours in food product development has been demonstrated in many studies (Badifu et al., 2000). Noodles are convenient pasta products which are second to bread in popularity as staple food. The carbohydrate contents of the blends and noodles containing soybean flour were lower than those of the WF and the $100 \%$ WF noodle due the dilution effect of wheat flour. Noodles have been reported to contain complex carbohydrate which provides long lasting energy and help individuals to feel full for long period of time (Izydorczyk et al., 2004). The use of SBF in noodles would promote the utilization of the flour in pastry.

Mineral composition: The mineral contents of soybean flour, wheat flour and their blends are shown in Table 3. Soybean flour contained $50.8 \mathrm{mg} / 100 \mathrm{~g}$ calcium, $48.3 \mathrm{mg} / 100 \mathrm{~g}$ magnesium $18.3 \mathrm{mg} / 100 \mathrm{~g}$ sodium, $110.3 \mathrm{mg} / 100 \mathrm{~g}$ potassium, $140.3 \mathrm{mg} / 100 \mathrm{~g}$ phosphorus and $1.2 \mathrm{mg} / 100 \mathrm{~g}$ iron. The calcium, magnesium, sodium, potassium, phosphorus and iron contents of wheat flour were $42,9,84.2,18.1,73.5,42.7$, and $1.9 \mathrm{mg} / 100 \mathrm{~g}$, respectively. The amounts of all the minerals increased with the level of soybean flour in the blends. The levels of the calcium, magnesium, sodium, potassium, phosphorus and iron in the noodles supplemented with soybean flour 170.7, $120.5,90.2,110.3,484.8$ and $3.1 \mathrm{mg} / 100 \mathrm{~g}$, respectively. These constituents were higher than those of the wheat flour and soybean flour. The addition of soybean flour improved the mineral composition of the noodles due to the excellent mineral composition of soybean flour. The minerals in the noodles are useful for the proper functioning of the body, Magnesium is an essential constituents of all cells necessary for the functioning of enzymes involved in energy utilization and it is present in the bone (WHO, 2003). The US RDA for iron is 10$15 \mathrm{mg}$ per day (WHO, 2003). The level of iron lends the noodles as a good source of iron. Iron is important in blood building. Deficiency of iron is the most common nutritional disorder in the world causing anemia that affects more than 3.5million people in the developing world (WHO, 2003).

Sensory properties: The sensory scores of the noodle samples are shown in Table 4 . There were significant differences $(\mathrm{p}<0.05)$ between the noodles produced from the $100 \%$ wheat flour and the noodles supplemented with soybean flour in the sensory properties assessed. The $100 \%$ wheat flour noodle (control) and noodle sample containing 40\% soybean flour had the highest scores for all the sensory attributes evaluated. The noodles containing $40 \%$ soybean flour was highly rated by the panelists for color, flavor, texture, taste and overall acceptability. There were significant differences $(p<0.05)$ for the scores for color, flavor, and the texture but the taste and overall acceptability scores for the noodles showed no significant differences $(p<0.05)$. The initial assessment of noodle quality is based on its visual appearance, color, brightness and absence of specks (Hatcher et al., 2009). Texture of cooked noodles is the most critical characteristic which determines the consumer acceptance of the product. The score for texture deceased with the level of the soybean flour in the noodle. The addition of soybean flour, non gluten flour diluted the strength of the wheat flour and interrupted as well as well weakened the overall structure of the noodles. The results are in line with the report of Ge et al., (2001) who reported that about $80 \%$ of the total protein of wheat flour is gluten. Gluten proteins are composed of gliadins and gluteins, which are responsible for the dough extensibility (viscosity) and strength (elasticity), respectively. Therefore, removal of wheat flour would impair the gluten matrix, hence leading to the weakening of noodle texture. There was more breakage in the noodles containing high levels of soybean flour probably due to the decreased amount of gluten in the noodles which lead to decreased binding. There was decrease in the overall acceptability of the noodles with increase in the level of soybean flour in the noodles.

Cooking characteristics: Table 5 shows the cooking characteristics of noodles prepared from wheat flour and soybean flour blends. The degree of 
cooking of noodles can be determined either by eye or image analysis (Lii and Chang, 1981). In the present study, cooking time was determined by the disappearance of the core of the noodle strand. The cooking time and cooking loss of the noodles increased steadily with increase in the level of the soybean flour in the noodles. The cooking time ranged between 7.19 and $9.45 \mathrm{~min}$. The cooking loss increased from $8.81 \%$ in the noodle containing $10 \%$ soybean flour to $11.25 \%$ for the noodle containing $50 \%$ soybean flour. The cooking loss is the amount of dry matter in the cooking water of optimally cooked noodles. The increase in the cooking loss with increased level of soybean flour may due to the weakening of the protein net work due to the addition of soybean flour (Baik and Lee, 2003). This would allow more solids to be leached out of the noodles into the cooking water. Gluten is primarily responsible for the texture of instant noodles and is the major factor that affects the cooking properties of noodles. The volume of the noodles decreased steadily with increase in the soy bean flour. The results are in agreement with the report of Sowbhagya and Zakuiddin (2001) who reported that partial or complete substitution of durum wheat semolina with fiber material resulted in negative changes in the pasta quality, including increased cooking loss. The ability of soybean flour to retain water probably caused reduction in the volume of noodles with increased level of soybean flour. The weight of noodles also increased with increase in the amount of the soybean flour in the noodles. Cooking time and rehydration are important features used to determine the quality of rice noodles (Fari et al., 2011). It was suggested that rice noodle should have short cooking time with negligible loss of solids into the cooking water (Fari et al., 2011). High cooking loss is undesirable as it indicates high solubility of starch which result in turbid cooking water, low cooking and sticky mouth feel (Fari et al., 2011)

\section{Conclusion}

Based on the results of this study, it is concluded that the incorporation of soybean flour into wheat flour improved the water absorption capacity and emulsion properties of the blends. The study also showed that $40 \%$ soybean flour could be incorporated into wheat flour to produce fried noodles without affecting the sensory and cooking characteristics of the noodles. The noodle supplemented with soybean flour had improved protein, fat, ash , crude fiber, calcium, magnesium, potassium, phosphorus and iron contents over the $100 \%$ fried wheat noodle. Thus, it is recommended that up to $40 \%$ soybean flour could be incorporated into wheat flour for instant fried noodles production. The storage stability of the instant fried noodles containing soybean should be determined. The health promoting potential of the fried noodles supplemented with soybean flour should be investigated.

\section{References}

1. Adenuga, M.O., Bakare, H.A. and Akinola, O.F. (2012).Enrichment of noodles with soyflour and carrot powder. Nigerian Food Journal, 30(1):74-81

2. Akpata, M.I. and Akubor, P.I. (1999). Chemical composition and selected functional properties of sweet orange (Citrus sinensis) seed flour. Plant Foods for Human Nutrition, 54: 353-362.

3. Akubor, P. I. and Chukwu, J. K. (1999). Proximate composition and selected functional properties of fermented and unfermented African oil bean (Pentaclethra macrophylla) seed flour. Plant Foods for Human Nutrition, 54 (3): 227-238.

4. Akubor, P.I and Eze, J.I. (2012). Quality evaluation and cake making potential of sun and oven dried carrot fruit. International Journal of Biosciences, 10(2):19-27

5. Akubor, P.I. (2016). Chemical composition and functional properties of African locust bean pulp flour and wheat flour blends. FUW Trends Science and Technology Journal, 1(1): 248-253.

6. Akubor, P.I. (2017).Effect of processing method on the chemical composition and functional properties of pigeon pea seed. Asian Journal of Advances in Agricultural Research, 2(2):1-8.

7. Anderson, J.W, Smith, B.M and Guitanson, N.S. (1994). Health benefits and practical aspects of higher diet. Journal of Clinical Nutrition, 545: 1242-1247.

8. AOAC (2010). Official Methods of Analysis $\left(20^{\text {th }}\right.$ edition). Association of Official Analytical Chemists, Washington, DC.

9. Badifu, G.I.O., Akubor, P.I. and Akpapunam, M.A.(2000). Chemical, functional and organoleptic evaluation of African breadfruit (Treculia africana Decne) kernel flour for 
making cookies. Tanzania Journal of Agricultural Science, 3(1): 31-38

10. Baik, B.K. and Lee, M.R. (2003). Effects of starch amylase content of wheat on textural properties of white salted noodles. Cereal Chemistry, 80: 304-309.

11. Compreeda, P., Resurrection, A.U.A., Hung, Y.C. and Beuchat, L.R. (1987). Quality evaluation of peanut supplemented Chinese type noodles. Journal of Food Science, 52:1740-1751

12. Eguono, E.E. and Akubor, P.I. (2016). Effect of debittering methods on the proximate composition, sensory and functional properties of orange (Citrus sinensis) seed flour. IOSR Journal of Environmental Science, Toxicology and Food Technology, 10(9): 9-16.

13. Fari, M.J.M., Rajapaksa, D. and Ranawara, K.D.S.(2011). Quality characteristics of noodles made from selected varieties of Sri Lankan rice with different physicochemical characteristics. Journal of Natural Science Foundation Si Lanka, 39(1):53-60

14. Fasasi, O.S. and Karim, O.R. (2011). Chemical composition, resistant, total starch content and acceptability of noodle substitutes with cowpea starch. Nigerian Food Journal, 29(1): 6-11

15. Ge, Y., Sun, A., Ni, Y., Cai, T. (2001).Study and development of defatted wheat germ nutritive noodle. European Food Resource Technology, 212: 344-348

16. Hatcher, D.W., Dexter, J.E., Anderson, M.J. and Bellido, G.G. (2009). Effect of blending durum wheat flour with hard white wheat flour on the quality of yellow alkine noodles. Food Chemistry, 113 (4): 980-988

17. Igbokwe, C.J., Akubor, P.I. and MbaeyiNwaoha, I.E. (2016). Effect of processing on the chemical composition, phytochemical contents and functional properties of yellow fleshed aerial yam (Dioscorea bulbifera) flour. INNOVARE Journal of Food Science, 4(4):14.

18. Ihekoronye, A.I. and Ngoddy, P.O. (1985). Integrated Food Science and Technology for the tropics. Macmillian Ltd, London.Pp 180189

19. Iwe, M.O. (2003). The Science and Technology of soybean. Concept Publications, Lagos, Nigeria.

20. Izydorczyk, M.S., Lagasse, M.S., Hatcher, S.L., Dexler, J.E. and Rossnagel, B.C. (2004).
The enrichment of Asian noodles with fiber rich fractions derived from roller milling of hull less barley. Journal of Science, Food and Agriculture, 85: 2094-2104

21. Jiang, H.Y., Lv, F.J and Tai, J.Q. (2000). Bioactive components of soybean and their function. Soybean Science, 19:160-164

22. Kinsella, J.E. (1987). Functional properties of proteins. Possible relationship between structure and function in foods. Food Chemistry, 7(2):275-288.

23. Lii, C.Y. and Chang, S.M. (1981).Characterization of red bean starch and its noodle quality. Journal of Food Science, 46:78-81

24. Liu, Z.F. (2000). Expanding soybean utilization and technology. Churchill, Living stone, Edinburgh

25. Nago, S. (1996). Processing technology of noodle products in Japan: In pasta and noodle technology. American Association of Cereal Chemists. St Paul, Mn USA, 168-194

26. Omeire, G.C., Umeji, O.F and Obasi, N.E. (2014). Acceptability of noodles produced from blends of wheat, acha and soybean composite flours. Nigerian Food Journal, 32(1): 31-37.

27. Onimawo, I.A. and Akubor, P.I. (2012). Food Chemistry (Integrated approach with biochemical background). $2^{\text {nd }}$ edition. Joytal printing press, Agbowo, Ibadan, Nigeria.

28. Puwani, E.Y., Widaningrum, R., Thahir, R. and Muslich, K. (2006). Effect of heat moisture treatment of sago starch on its noodle quality. International Journal of Agricultural Science, 6(4):23-30

29. Reungmanee paitoon, S.(2009). Development of instant fried noodles made from composite flour of wheat and sweet potato flours. Kasetsart Journal (Natural Science), 43: 768779

30. Ritthnuangde, J. P., Panbankled, S., Doncheedee, S. and Wongsagonsap, R. (2011).Physical, chemical and sensory properties of fried wheat noodles supplemented with unripe banana flour. Kasetsart Journal (Natural Science), 45: 500509.

31. Sanni, L.O., Bamgbose, C.A., Babajide, J.M and Sanni,S.A. (2007). Production of instant cassava nodles.In: Proceedings of the $13^{\text {th }}$ Treinnial Symposium of the International Society for Tropical Root Crops (ed Kapinga 
et al)10-14 Nov, 2003, Arusha, Tanzania, pp. 466-472.

32. Sathe, A.K., Desphande, S.S. and Salunkle, D.K. (1982). Functional properties of lupin seed protein and protein concentrates. Journal of Food Science, 42:491-498.

33. Sowbhagya, C.M. and Zakuiddin, A. (2001). Vermicelli noodles and their quality assessment. Journal of Food Science and Technology, 38: 423-432.

34. Sui, Z., Lucar, P.W. and Corke, H. (2006). Optimal cooking time of noodles related to their notch sensitivity. Journal Texture Studies, 37: 428-441

35. Ubbor, S.C. and Nwaogu, C.E. (2010). Production and evaluation of noodles from blends of cocoyam, breadfruit and wheat. Nigerian Food Journal, 28(1):173-187

36. WHO (2003). Postharvest and processing technology of staple foods. Technical Compendium, WHO, Agricultural Science Bulletin, 88: 171-179.

$\begin{array}{ll}\text { Received } & \text { : Aug., } 2018 \\ \text { Revised } & \text { : Sept., } 2018 \\ \text { Published } & \text { : Dec., } 2018\end{array}$

